\title{
The Critical Perspective of English Language Testing and Assessment within Framework of Elana Shohamy
}

\author{
Ali Siddiqui ${ }^{1 *}$, Shabana Sartaj², Syed Waqar Ali Shah ${ }^{3}$ \\ ${ }^{1}$ English Language Development Center (ELDC), Mehran University of Engineering and Technology (MUET), Jamshoro, Sindh, Pakistan \\ ${ }^{2}$ Department of English, Sindh Agriculture University, Tandojam, Sindh, Pakistan \\ ${ }^{3}$ English Language Development Center (ELDC) Mehran University of Engineering and Technology (MUET), Jamshoro, Sindh, Pakistan \\ Corresponding Author: Ali Siddiqui, E-mail: scorpion_king2893@hotmail.com
}

\begin{tabular}{|c|c|}
\hline ARTICLE INFO & ABSTRACT \\
\hline Article history & \multirow{9}{*}{$\begin{array}{l}\text { The language assessments and testing are the crucial aspects of teaching and learning processes. } \\
\text { Therefore, the following study is aimed to focus on these two most important aspects with refer } \\
\text { to a critical view on its practical aspect that is after passing through a tactful teaching process. } \\
\text { The crucial notion of practicing language assessments as well as testing towards a critical sense } \\
\text { was initiated by Elana Shohamy in her critical works. It was after her thorough observations and } \\
\text { experimentations of testing within various learning disciplines, the present study is designed as a } \\
\text { review on some of particular testing structures that has been observed under influence of power, } \\
\text { hegemony and biasedness with respect to social elements that encounters it. Therefore, it is } \\
\text { quite necessary to highlight a prospective of Elana Shohamy, who has tried her best to arrange a } \\
\text { valuable platform in order to discuss the related issues critically regarding testing procedures. In } \\
\text { the end, reasons provided by Elana Shohamy has been highlighted that can verily show that test } \\
\text { itself cannot be a fully trusted authority. It can be a challenging aspect at any rate that could be } \\
\text { dealt accordingly in order to restore its very nature of being neutral in every respect. }\end{array}$} \\
\hline Received: April 21, 2018 & \\
\hline Accepted: August 1 & \\
\hline Published: October 31, 2018 & \\
\hline Volume: 9 Issue: 5 & \\
\hline Advance access: August 2018 & \\
\hline Conflicts of interest: None & \\
\hline Funding: None & \\
\hline & \\
\hline
\end{tabular}

Critical,

Assessment,

Testing, Power,

Control,

Language

\section{INTRODUCTION}

This article consists of the perspective that what is Assessment? Then, it follows on, what is testing? Finally, it aims to identify what is language testing? And why the language testing is so critical?

\section{Purpose of this Study}

The purpose of this study is to investigate the language Assessment and Testing in the perspectives of the complexities in the process of language teaching. How tests are associated with Power? How tests can change one's life. How testing influence the teaching scenario and how high Stake Tests works as a barrier for people who believes English Language as the passport to enter into the English Countries.

\section{Significance of the Study}

This study is an attempt to know the complexities, difficulties and challenges that arises while to design, conduct, and assess, the effects of a test that is mainly concerned with a High stakes test.

\section{Research Problem}

The idea of language testing has been changed with past times. Earlier, the notions of language testing and assessments have not been researched on critical basis. However, these important notions of language teaching have been taken as granted by language teachers and test takers without any concern on point of contextual variations.

\section{Aim of the study}

The present study is designed to know the critical aspect of language testing and assessment. This important aspect of critical design in evaluating the language test itself is based on Elana Shohamy's approach.

\section{Objectives of the study}

The study has few objectives. The present study is designed to present the actual concepts of language testing and assessment according to critical perspective framework of Elana Shohamy.

It will tend to highlight the following objectives with critical evaluation of following topics: 
- What is assessment?

- What is testing?

- Why is language testing critical?

- To know how the power of testing controls over masses?

\section{LITERATURE REVIEW}

\section{What is Assessment?}

The depiction of language and language learning has essential properties for the assessment of language. First, since it is the object of an assessment is to evaluate the thing and second since it is the medium of assessment (the methods through and inside of which one surveys). Instructional results in the language expressions, assessment strategies and practices that ought to reflect what one thinks about language and its scoring. For instance, to construct a test with respect to the presumption, there is a solitary right approach to compose an enticing exposition which can have a questionable practice. Inducing somebody to purchase a house is not the same as influencing somebody to go out to the town. Influencing somebody in a less capable position is not the same as convincing somebody in an all the more intense position - which is to say that powerful practices vary crosswise over circumstances, purposes, and social gatherings. Additionally, that messages can (and ought to) be perused from alternate points of view must be taken as a sureness; an objective of educating that is not to be upset by assessment rehearses, however it imagines generally. It is to affirm through various decisions that test is a bit of content which has a stand out importance taken as unsatisfactory and given what we know of language.

\section{What is Testing?}

It is a technique to decide an under-study's capacity for finishing certain errands or towards show an authority of an expertise for information of substance. A few sorts can be made for numerous decision tests, or a week by week spelling test. While it is usually utilized reciprocally with assessment, or even assessment, it can be recognized by the way that a test is one type of an assessment.

Language testing is one of those uncommon sciences which skew towards observational methodology, (Farhady 2006, Shohamy 2001); (McNamara and Roever, 2006) and Shohamy (1997). They contends that the power of tests is because: (1) test producers claim the scores and people as surviliant, (2) They choice producers for alluding test scores and to practice power in instructive projects, finally (3) scores are thought to be valid data about test takers' capacity since target measures were executed to assemble them. That target dresses provide food for the power of test and welcomes a general guideline. As McIntyre (1984) claims that since chiefs are to modify and intended to the finishes proficiently, scores are valid since they are logical information apparently crystalized by numbers. At the end of the day, the test scores are regarded to follow where there are no different numbers and opponent them (Hanson, 1993); the same objectivity and appeal to rationality legitimize testing practices (Broadfoot 1996).

\section{Power and Language Testing}

Rea Dickins (1997) contends that a great deal of partners are impacted by test scores extending from understudies to instructors, folks, chairmen, Government operators to subsidizing associations, and to distributers, for open. Farhady (2006), alluding to the occasion of IUEE characterizes all these partners into instructive, social and political gatherings, attests that each bunch has an alternate sort of enthusiasm and expectation for using tests wellspring of power.

The instructive gathering includes understudies, instructors and educator mentors that nurture more test quality as they are the most influenced gathering with respect to the results. Educators for the most part attempt to focus on the subjects that might show up in the test and their own needs, arranging and teaching are even shadowed to the detriment of would-be tried materials and procedures. It is confusing that both understudies and educators and here and there indeed, even folks are discerning that what shows up in the IUEE and the practices they render amid class hours are not in accordance with the present techniques for language teaching and learning (Barootchi and Keshavarz, 2002; Hamayan 1995; Tsagari, 2004). However reminiscent of conventional strategies (e.g., Sentence structure Interpretation techniques) for language learning and teaching (Mahdavinia and Rahimi, 2011), still they do not dither to act per the test needs as their scholarly and social power may not past this since they are controlled to act in specific ways (van Dijk, 2003; Bloor and Bloor, 2007). The social setting grasps different gatherings with regards to social class and every gathering might translate test scores in an unexpected way. Farhady (2006) clarifies that a few families may be fanatical about scores and uphold a few changes in the family undertakings to give a superior circumstance to their youngsters to pass IUEE since they know the outcome influences the eventual fate of test takers and the family while a few families could not care less about the outcomes and the test process goes ahead without influencing the families' common way.

\section{Scholarly Contributions on Testing}

Some researchers even trust that tests are critical and they are utilized for control (Shohamy, 2001). High-stakes tests are one-sided as they concentrate on local speaker standards (Brown, 2004; Davies et al., 2003; Khan, 2009). There is a solid feedback of high-stakes global English examinations, (for example, IELTS and TOEFL).These tests are particular to inward however mainly towards assortments of English in the United Kingdom and the United Sates (Davies et al., 2003). Davies et al. (2003) led a study to evaluate whether high-stakes universal English examinations are one-sided against non-local speakers of the language that are might capable in utilizing English for global correspondence? Or have not been presented to specific subtleties of an inward hover assortment of English. These tests speak to the old pilgrim Standard English of the UK, USA, and so forth. It is a sort of English that is not known, or just mostly known, to huge numbers of the individuals who have learnt English as an extra language (e.g., India, Singapore and Malaysia)' 
(2003:571). They estimated in the start of their article that global English tests are one-sided, as they require a specific sort of English from possibility to which they have not been uncovered. The creators reported the vicinity of inclination in global tests, for instance, TOEFL is one-sided against the individuals who might be capable in utilizing English as a worldwide language, and still they are not acquainted with American English. They found few words in the TOEFL test that have diverse implications in British, American and Australian English. They likewise discovered words that are socially particular to North American connections.

Brown (2004) recognized two particular levels of inclination:

At the test thing level, and

At the tests score level.

Brown (2004) recommended that test predisposition originates from different sources inside of the testing process that includes organization methodology, test content, test information determination, testing strategy and rating or scoring. He recorded eight classes that affected tests. He trusts that a test is free from predisposition if every one of the eight "Englishes" are the same as shown under: the English(es) of the test-takers' nearby group, the prevailing English of the test taker, the English(es) of the test content, the English(es) of the test delegate, the English(es) of the test scores, the English(es) of the choice target group, the English(es) of the choice target reason, and the English(es) of the leaders.

Khan's study (2009) on TOEFL investigated inclination against non-local speakers. She directed a contextual analysis at a private school in Jeddah, Saudi Arabia where TOEFL is utilized as a placement test. It focuses on (a) Perceptions of educators and students and (b) Focus gathering along with semi-organized meetings. Perspectives of the members in Khan (2009) TOEFL is considered as a "conductor to Americanisation', TOEFL speaks to Americanisation in Saudi Arabia, it was Preferred because of Multiple decision inquiries. A part of the top administration considered in the United Stated where TOEFL was the standard.

"The Educational Imperialism" (Phillipson, 1992) said that the Policy Makers in instructive field keep up their solid connections to inward circle nations and have a tendency to advance the instructive philosophies of those nations, subsequently reinforcing the 'authority towards internal circle nations' (2009:198). It is utilized by schools as an 'advertising ploy' to inspire students and expansion enrolment. Students felt that TOEFL not only is suitable for students as it uses American English but is useful for cultural substance and American English lingo.

\section{WHY IS LANGUAGE TESTING SO CRITICAL?}

Here are the reasons given by Elana Shohamy, why she thinks the language test is critical.

\section{Test as a Method for Control}

Elana Shohamy (1998:332) has built up a structure known as critical language testing (CLT) which manages the social and political part of tests. She says that Testing is not neutral.

\section{Testing is not Neutral}

According to Shohamy (1998:332), 'tests are most capable as they are frequently used as single pointers for deciding the fate of people. As criteria for acknowledgment and dismissal, they overwhelm other instructive gadgets, for example, educational programs, course reading and educating'. Tests can have a gigantic impact on the lives of test takers, as they make champs and washouts, triumphs and disappointments, dismissals and acknowledgments (Shohamy, 2001:16). It is because of these inconvenient impacts, test-takers are frequently eager to do anything as to accomplish the most extreme scores. Hence, tests can be utilized as disciplinary apparatuses, for instance test-takers can be compelled to change their conduct to meet the requirements of the test. Tests influence a scope of partners, for example, students, educators, folks, managers, government specialists, subsidizing associations and national instructive bodies. These partners can be ordered into instructive, social, and political gatherings where every gathering has an alternate sort of enthusiasm for, and expectation for, using tests as a wellspring of force. The High Stakes Tests are the Centralised instructive frameworks that forces specific information. The discipline of Politics, decides by the given scores about having a citizenship, control movement to a gate-keeper. She advocates 'critical testing' which elevates critical procedures to research the utilizations and results of tests, to screen the force of tests, to minimize their hindering strengths, to uncover abuses and engage the test takers.

\section{ASL Test in Israel}

Shohamy (1993) researched the effect of ASL test in Israel. In order to raise the notoriety of Arabic language among Hebrew speakers, she found that the test affected educating and learning exercises as the instructors supplanted reading material with worksheets indistinguishable to test materials that directed "test-like" exercises in class and arranged students particularly for the test before its occurrence. Standard of Arabic is not raised in view of low distinction.

\section{EFL in Israel}

\section{"EFL oral capability test"}

It is the test through which Teachers pay concentration on oral language. Teachers invest impressive energy showing oral language aptitudes. However it just utilized errands and exercises that are indistinguishable to those incorporated into the test. According to Shohamy (1996) investigation ASL sway went on for brief timeframe contrasted with EFL. 'Washback can change after some time and that the effect of tests is not as a matter of course steady'. It relies on upon various variables, for example, language status, the motivation behind the test, the arrangement of the test, and the abilities that are tested.

\section{Moore's Utilization of CLT (Critical Language Testing)}

Moore et al. (2012) consider the IELTS test as restricted of controlling and forcing particular information on students 
and instructors. The IELTS test is controlled by western foundations as an entryway keeping instrument for movement. It is helpful as a passage into advanced education, in a way the Cambodians are liable to the principles and regulations forced by these organizations.

\section{CONCLUSION}

The English language which is utilized as a part of TOEFL does not mirror the English (es) that has been utilized by the worldwide speakers of English language (Khan, 2009:199). It is so, as some of the idiomatic expressions which are particular to North American society are not understood by students on the other edge of the World. It is by considering this point, 'English must not be the property of a single country; it should be internationalized more in the way that it is taught and is tested'. The English language tests ought to be designed by incorporating "nonpartisan" substances and therefore must not benefit a particular society. According to (Khan, 2003:203), the test takers do experiences the psychological submissive attitude with the standardized high stake tests because it is troublesome, long and unseemly advances one community onto other just like an American English: within TOEFL is one-sided. Khan (2009:193) proposes that the standardized test of TOEFL is not helpful test for second and remote language connections in light of the fact that English, which is used as part of these neighbourhood settings is more worldwide than American in every aspect. It was Elana Shohamy's valuable critical contribution towards testing and assessment which has really helped the English applied linguists and teachers to modify the research mode of language testing field and teaching strategies to better design the test with nonpartisan attitude. It is only possible through analysing the very social aspects that tend to portray language test as an imperialistic design for its takers.

\section{REFERENCES}

Alderson, J. C. (2001). Language testing and assessment. Language Teaching, 213-236.

ALTE. (2011). Manual for Language Test Development and Examining.

Longman, E. S. (2003). The Power of Tests. 55-60.

Lynch, B. K. (2001). Rethinking assessment from a critical perspective. Language Testing, 18(4), 351-372.

Piggin, G. (2006). What are our tools really made out of ? A critical assessment of recent models of language proficiency Gabrielle Piggin What are our tools really made out of ? A critical assessment of recent models of language proficiency. 79-87.

Shohamy, E. (2009). Language tests for immigrants: Why language? Why tests? Why citizenship. Discourses on language and integration, 45-59.

Shohamy, E. (1993). The Power of Tests: The impact of language tests on teaching and learning. Washington, DC: The National Foreign Language Centre at John Hopkins University.

Shohamy, E. (1998). Critical language testing and beyond. Studies in educational evaluation, 24(4), 331-345.

Shohamy, E. (2001). The Power of Tests: A Critical Perspective on the Use of Language Tests, Harlow: Pearson Education.

Shohamy, E., Donitsa-Schmidt, \& Ferman, I. (1996). Test impact revisited: washback effect over time. Language Testing, 13(3), 298-317. 